VI. A ppeal to quarter sessions.-Any person who has been convicted of any offence punishable by this Act may appeal to the next general or quarter sessions of the peace which shall be held for the city, county, town, or place wherein such judgment or conviction shall have been made, provided that such person enter into a recognizance within two days next after such convietion with two suficient sureties conditioned to try such appeal, and to be forthcoming to abide the judgment and determination of the justices at such general or quarter sessions, and to pay such costs as shall be by such last-mentioned jus. tices awarded; and the justices before whom such conviction shall be had are hereby empowered and required to take such recognizance; and the justices at such general or quarter sessions are hereby authorized and required to hear and finally determine the matter of every such appeal, and they may, according to their diseretion, award such costs to the party appealing or appealed against as they shall think proper.

VII. Where conviction within six days of quarter sessions, time allowed for appeal. - If any such conviction or judgment or order of forfeiture shall happen to be made within six days before any general or quarter sessions of the peace shall be held for the city, county, town, or place wherein such conviction shall have been made, the person who shall think himself aggrieved by any such conviction may, on entering into a recognizance in manner and for the purposes before directed, be at liberty to appeal either to the then next or next following general or quarter sessions of the peace which shall be held for any such city, county, town, or place wherein any such conviction shall have been made.

VIII. Procedure and application of penalties. -The provisions in the Nuisances Removal Act for England, 1855, as to procedure, and the provisions of the Act of the eleventh and twelfth years of the reign of her present Majesty, intituled "An Act to facilitate the Performance of the Duties of Justices of the Peace and of Session, within England and Wales, with respect to summary convictions and orders," so far as the same are respectively applicable, shall extend and apply to cases arising under this Act; and all moneys arising from penalties under this Act in any district or borough where there are analysts appointed under this Ant shall, when paid or recovered, be paid to the vestry, district board, or town council for such district or borough respectively, to be applied for the general purposes of such vestry, district board, or borough respectively.

IX. Cost of executing $A$ ct. - ' I he expense of executing this Act shall be borne, in the metropolis, out of any rates or funds applicable to the purposes of the Act for the Better Local Management of the Metropolis, and in boroughs out of the borough fund.

X. Interpretation of terms in Act.-In the construction of this Act the words "articles of food or drink" shall (if not inconsistent with the context or subject matter) include not only all alimentary substances, whether solids or liquids, but also all eatables or drinkables whatsoever not being medical drugs or articles usually taken or sold as medicines.

XI. Extent of Act.-This Act shall not extend to Scotland or Ireland.

\section{POOR-LAW MEDICAL REFORM ASSOCIATION.}

ON the 24th ult., a very numerous and influential deputation of about forty of the members of this Society, both metropolitan and provincial, waited upon Mr. Sotheron Estcourt, the President of the Poor-law Board, for the purpose of representing to him the inadequacy of the remuneration at present paid to Poor-law medical officers, and of placing before him some of the hardships and anomalies of their professional position.

The deputation included Mr. Griffin, of Weymouth, chairman of the Association; Dr. Rogers, of the Strand Union; Dr. Williams, of Carnarvon; Dr. Prior, of Bedford; Mr. Lord, of Hampstead; Mr. Ransom, \&c.

The deputation was introduced by Mr. Pigott, M.P., in a few appropriate observations.

Mr. GRIFFIN, of Weymouth, chairman of the Association, then entered into a very able and elaborate statement of the whole case, and the mode which he proposed should be adopted to remedy the admitted evils of the present system. First, then, he proposed that the appointments should be permanent, subject to Article $V$., with power to resign, on giving reasonable notice, as at present. Secondly, that for the future medical officers shall have the double qualification (medical and surgical) in accordance with 21 st and 22 nd Vict., cap. 96 , but present medical officers not to be displaced on account of the single qualification. And thirdly, that there shall be a uniform scale of payment throughout the United Kingdom. 250
Dr. Rogers, Dr. Williams, of Carnarvon, Dr. Prior, of Bedford, and several other gentlemen, addressed the President.

The PRESIDEN'r then said that he felt obliged to the gentle. men who had come so many miles to confer with him on the subject, and for the information which they had given him. $\mathrm{He}$ paid a high compliment to Mr. Griffin for the tact and ability he had displayed in the matter. It was hopeless, he said, to think of passing any measure this year; but he would give all the points his best consideration, and draw up a Bill introduce it, print and circulate it, and in the next session of Parliament, when it had been thoroughly ventilated so as to give satisfaction as widely as possible, it might be pressed on with some chance of being carried. They seemed to have become much more united amongst themselves; the Board ad. mitted the existence of the evil, and felt disposed to do some thing to remedy it; and, on the whole, he certainly thought the matter was progressing favourably.

After thanking the President for his courtesy and attention, the deputation withdrew.

\section{Contespomonte.}

$$
\text { "Audialteram partem." }
$$

\section{DIPHTHERIA.}

[LETTER FROM DR. JOHN LOWR.]

To the Editor of The LANCET.

SIR,-I have read with rnuch interest the letters of Professor Laycock and Drs. Rogers and Harley which have lately ap. peared in the pages of The LANCET. As the topic is one to which I have given a considerable degree of attention, it will, perhaps, not be deemed presumptuous if I venture a few brief remarks thereon.

Dr. Rogers, in his letter, states positively that oidium albicans is not found in diphtheric cases, and that Dr. Laycock's theory is therefore erroneous. M. Jodin avers, that both croup and diphtheria are merely "affections parasitaires ou moisissures." (Gaz. des Hôp., Oct. 16th, 1858.) Two widely different statements-how to be reconciled? The observers who hold the latter opinion in France are by no means few, and have had ample opportunities of judging whether they were dealing with true or false diphtheria. It is quite possible that they may, as Trousseau imagines M. Loiseau did, mistake " angine couenneuse" for "angine diphthérique;" but this seems scarcely probable, as many of their cases appear to have proved fatal by the spreading of the diphtheric membrane to the air passages; at least such are the statements of Duché, Jodin, and others.

In the only case which I have had an opportunity of examin. ing microscopically (for, happily, we have enjoyed almost com. plete immunity from the epidemic), there was abundance of the oidium in a portion of pseudo-membrane ejected from the trachea. After death, the air-passages were found to be lined with exudation to the fourth bronchial ramification, and the fungus was exceedingly abundant throughout. There could be no mistake in its being real fungus, which, in my opinion, is readily distinguishable from fatty acids or any other product.

It may be remarked that the " herpetic" manner in which the pellicle spreads is rather in favour of the fungus theory. This was particularly noticed by Mr. Cammack, of Bennington, (THE LANCET, Oct. 30th, 1858,) and is peculiarly the character of fungal growths.

The leptothrix buccalis, observed by Dr. Wade, is certainly common, as Dr. Rogers states, in healthy persons, and there can be little doubt is merely an initial state of oidium albicans, the spores of which also may almost always be found on the gums. Under ordinary circumstances, these fail to attain a higher form; but when favourable conditions ensue, as in muguet, \&c., they become elevated into the oildium. What these conditions are remains as yet unknown. An acid state of the buccal mucus, as asserted by Gübler, is, I think, not yet proved to be the essential; on the contrary, the fungus itself is the acidifying agent, as proved by the experiments of Professor Balfour; and the late Dr. Pereira further demonstrated that acid is inimical to its growth. My own experiments show that the fungus has tpree distinct powers: first, as the spore, pro 
ducing alcoholic fermentation; second, as the mycelium, producing acid, without the intervention of vinous fermentation; and, third, on the exhaustion of the acid or sugar, inducing putrefactive decomposition. I might observe, that another peculiarity of the fungus is that of retaining, under certain conditions, a uniform state of development. Thus, I have found the nuclei produced by the bursting of yeast-cells ("globulin" of Turpin ?) to be capable of almost endless reproduction as nuclei, having a diameter of 10,000 th of an inch. In this form they are possibly received from the air into the circulation, and may give rise to sarcina in the kidney (for sarcina is now thought, on good grounds, by Mr. Berkeley, to be produced by penicillium or aspergillus). Again, I have seen these nuclei develop into cells, in which form they are also capable of endless extension as yeast. Attaining the higher form of the mycelium, they may be produced indefinitely as the vinegar-plant.

As I have elsewhere endeavoured to show, the whole group of parasitic fungi have origin from one or two common species of mould. Thus the frequency of skin diseases in dirty and ill-ventilated dwellings is no mystery.

In conclusion, I would observe that in the foregoing remarks I do not venture to advocate a theory in favour of a diphtheric parasite. I would merely say that, in the presence of so much contrariety of opinion, it were well that further inquiries should be instituted; for while it is fully admitted that the disease is infectious, it is by no means proved what the morbific agent is. I am, Sir, your obedient servant,

King's Lymn, Feb. 1859. JoHY Lowe, M.D.

P.S.-I observe that Dr. Harley proposes to institute experiments as to the effects of fungi in the blood, by injecting the mycelium and spores into the vessels. Now, as these have a diameter greater than that of blood-globules, they would probably be arrested in the capillaries, and there undergo disintegration, or else excite local inflammation. Might I suggest, that the value of the experiments would be enhanced by making use of the fungus in a state wherein the diameter of the cellules is less than that of the blood-corpuscles-e. $g .$, yeast, exposed for a lengthened period to the atmosphere, and which has become pulverulent by the bursting of the cells, and escape of the contained granules, which have a diameter of from the 10,000 th to 7000 th of an inch.

\section{THE ANATOMY ACT.}

[NOTE FROM CHARLES HAWKINS, ESQ.] To the Editor of The Lancet.

SrR,-It is not my intention to enter into any discussion at present with regard to the working of the Anatomy Act. But as I am sure you would not wish that your journal should contain any incorrect information, I am led to notice the following statement, made by an anonymous correspondent, in THE LAXCer of the 26th ult.:-

"In the medical school I attend, there are about two hundred students engaged in the pursuit of practical anatomy and, up to this time, only twenty-five subjects have come in."

You may state, Sir, on my authority, if you think it worth while, that there is no school in London with even one hun. dred pupils that has not had upwards of twenty-five subjects; indeed a school with less than one hundred pupils has had more than twenty-five. There is no school in London with two hundred registered pupils.

$$
\text { I am, Sir, your obedient servant, }
$$

Savile-row, Burlington-gardens, CHAS. HAWKINS, F.R.C.S., February, 1859 Inspector of Anatomy.

\section{THE NEW MILITARY MEDICAL SCHOOL. To the Editor of The LANCET.}

SIR,-I am delighted to see that you bave called attention, by the insertion in your journal of 26 th ult. of the very sensible letter of "A Last Year's Man," to the scheme proposed by Miss Nightingale of sending all the young army surgeons to school. "When a lady's in the case, all others must give place;" but, in my opinion, the lady herself is out of place in a question such as the present, where she dabbles in a matter that she cannot understand. Soup kitchens and extra issues are her province, and for those duties no woman on earth is better fitted; but for drawing out of schemes for military medical education she is totally unsuited, and no better proof of this can be given than by referring to her contemplated intention of founding this school for the teaching of clinical medical surgery. She has hitherto had her own way, uncontrolled; but licenee enough has certainly been given to this good lady, and as she seems now bent on going from the sublime into the ridiculous, let some limit be placed on her ideas.

This school may be all very pretty in theory, but practically it would be a perfect nuisance. It would deter candidates from entering, for the desirable men, the really well-educated, would not stand this nonsense. I know that there is nothing which the army surgeon can be taught at home that he cannot learn equally well whilst a student, without anything more than a local professorship, such as that at Dublin, and that no special school is needed.

March, 1859 . I am, Sir, your obeäient servant,

A Stafr-SURgeon.

\section{NOVEL SUBSTITUTE FOR A FEMALE CATHETER. \\ To the Editor of The Lancet.}

SIR,-Should you deem the following incident of sufficient interest to your numerous readers, you will do me the favour to give it a place in your journal:-

Un June 3rd, 1858, I made a professional visit to a female patient who was suffering from a severe attack of typhus fever. Upon inquiry, I learnt that she had passed scarcely any urine for several hours; and, on examination, found an enormous abdominal enlargement from distension of the bladder. I at once determined, if possible, to empty it; but being about six miles from home, and having no catheter with me, I resolved on trying to construct one with a quill. I obtained a knittingneedle with a circular head, passed it through a piece of quill,
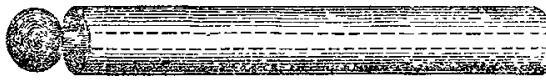

and, by keeping them in apposition, readily introduced them into the bladder, and succeeded, by forcing the head of the needle slightly beyond the end of the quill, in emptying it. I am, Sir, your obedient servant,

Chichester, February, 1859. AlLEN DUEE, M.D.

\section{THE NEW MEDICAL ACT.}

\section{To the Editor of THE LANCET.}

SIR,-Perceiving by the last number of THE LANCET that a Bill is brought into Parliament to amend the Medical Act of IS58, may not the "gross monopoly" which you drew attention to in THE LANCET of the 18th of December last, in the appointment of medical officers to the county infirmaries in Ireland, be rectified merely by stating, in Clause 36 of the said Medical Act of last session, that all persons duly registered under that Act are eligible to be appointed as medical officers to all infirmaries, hospitals, or other medical institutions in the United Kingdom; that no one shall hold any of these situations until first registered in accordance with the said Medical Act?

Now that an opportunity occurs to do away with every monopoly, not before provided for, your well-merited influence is looked to to get the defect remedied.

March, 1859. I am, Sir, your obediente servant,
A SUBSCRIBER.

\section{TURNING VERSUS CRANIOTOMY. To the Editor of THE LANCET.}

SIR,-During my stay with a medical practitioner of Rochdale, I was requested, during his absence from home, to attend a Mrs. S-, who lived about two miles in the country. On my arrival, I found her in labour with her seventh ehild. To my surprise and astonishment, on inquiry, I was informed that craniotomy had been performed in all her previous labours by that gentleman. On an examination per vaginam, I found a foot presenting, and that the promontory of the sacrum lessened to some considerable extent the antero-posterior diameter of the pelvis. I experienced no difficulty in the extraction of the head, the chin being well pressed on the chest. A fine child was born alive; they both did well.

Two years afterwards I was summoned again to attend Mrs. S- On examination, I found the head presenting above the pelvic brim, os uteri fully dilated, membranes unruptured. From the facility with which I succeeded in her previous con 